\title{
İş-Aile Rol Çatışması ve Kariyer Devamlıı̆̆ı İlişkisi: Kadın Turist Rehberleri Üzerine Bir Değerlendirme*
}

\section{The Relation Between Work- Family Conflict and Career Continuity: An Evaluation on Female Tour Guides}

\author{
Öğr. Gör. Dr. Nilgün DEMİREL \\ Iğdır Üniversitesi, Iğdır Meslek Yüksekokulu, Türkiye \\ Igdir University, Igdir Vocational High School, Turkey \\ E-Mail: nilgun.demirel@igdir.edu.tr \\ Dr. Öğr. Üyesi Yurdanur YUMUK \\ Karabük Üniversitesi, Safranbolu Turizm Fakültesi, Türkiye \\ Karabuk University, Faculty of Safranbolu Tourism, Turkey \\ E-Mail: yumukyurdanur16@gmail.com
}

Prof. Dr. Necdet HACIOĞLU

İstanbul Gelişim Üniversitesi, İktisadi ve İdari Bilimler Fakültesi, Türkiye Istanbul Gelisim University, Faculty of Economics and Administrative Sciences, Turkey

E-Mail: nhacioglu@gelisim.edu.tr

$\ddot{O} z$

Amaç ve Önem: Araştırmanın temel amacı evli kadın turist rehberlerinin iş-aile rol çatış̧ası algıları ile kariyer devamlılığı eğilimleri arasındaki ilişkiyi ortaya koymaktır. Türkiye'de seyahat acentelerine bağlı veya bağımsız olarak çalışan kadın turist rehberlerinin sayısının erkek turist rehberlerine oranla az olması, turist rehberliği mesleğinin erkek mesleği olarak görülmesi ve kadın turist rehberlerinin üstlendikleri çoklu roller gereği iş-aile çatışması yaşamaları ve bu nedenle mesleklerini devam ettirememeleri kadın turist rehberlerinin sorunları üzerine odaklanmayı gerekli kılmaktadır.

Yöntem: Araştırmada amaca uygun olarak nitel (kalitatif) araştırma yöntemi ve olgu bilim (fenomenoloji) araştırma deseni kullanılmıştır. Örneklemin belirlenmesinde amaçlı örnekleme yöntemlerinden olan kartopu örnekleme tercih edilmiştir. Yarı yapılandırılmış mülakat formu aracıllğı ile yüz yüze ve telefonla görüşmeler sonucu elde edilen veri, MAXQDA (demo) nitel veri analiz programı ile değerlendirilmiştir. Veri analiz stratejisi olarak içerik analizinden yararlanılmıştır.

Bulgular: Betimsel analizler sonucunda kadın turist rehberlerinin en çok bahsettiği alt tema çocuklar ve eş olarak saptanmıştır. Kadın turist rehberlerinin daha çok düşük düzeyde gerilim temelli çatışma yaşadıkları ortaya konmuştur. Çoğunlukla aile-iş çatışmasının yaşandığı, ailevi sorumlulukların iş ile ilgili sorumlulukların önüne geçtiği belirlenmiștir. İlişkisel analiz sonucunda eși turizm sektöründe çalıșan veya turist rehberi olan kadın turist rehberlerinin kariyerlerini sürdürmek istedikleri sonucuna ulaşılmıștır. Bazı kadın turist rehberleri ise çocuklarına yeterince vakit ayıramamak, ailevi ilişkilerini dengede tutamamak veya uzun süreli turlara çıkmak gibi nedenlerle kariyerlerini sürdürmek istemediklerini belirtmişlerdir.

Özgünlük/Bilimsel Katkı: Turist rehberliği üzerine yapılan ve özellikle kadın turist rehberlerinin sorunlarını iş aile çatışması ve kariyer devamlılığı ilişkisi açısından ele alan çalışmaların yetersizliği nedeniyle araştırmanın literatüre ve sektöre önemli katkılar sağlayacağı düşünülmektedir.

Sınırlılıklar: Araştırmaya yalnızca Türkiye'deki eylemli kadın ve evli turist rehberlerinin dâhil edilmiş olması araştırmanın en önemli kısıtını oluşturmaktadır.

Atıf için (for cited); Demirel, N., Yumuk, Y. ve Hacıoğlu, N. (2021). İş-aile rol çatışması ve kariyer devamlılı̆ğ ilişkisi: kadın turist rehberleri üzerine bir değerlendirme, Turist Rehberliği Dergisi, 4(1), 48-63.

* Bu çalışma, III. Ulusal Turizm Kongresi’nde sözlü olarak sunulan bildirinin geliştirilmiş halidir. 
Uygulanabilirlik: Sosyal bilimlerde gerçekleştirilen araştırmalarda "kültür" olgusunun araştırma sonucunu etkileyen son derece önemli bir faktör olduğu kabul edilmektedir. Bu nedenle, araştırmanın kadına farklı anlamlar yüklendiği Batı kültürlerinde tekrar edilmesinin araştırma sonucunu değiştirebileceği düşünülmektedir. Seyahat acentelerinin daha fazla sayıda turist rehberi çalıştırmalarının kadın turist rehberlerinin dönüşümlü olarak turlara çıkmaları ve böylece ailelerine daha fazla zaman ayırabilmeleri açısından önemli olduğu kabul edilmektedir.

Anahtar Kelimeler: İş- aile çatışması, kariyer devamlılı̆̆ı, kadın turist rehberleri.

Makale Türü: Araştırma makalesi

\begin{abstract}
Purpose and Importance: The main purpose of this research is to reveal the relationship between female tourist guides' perception about work-family conflict and tendency of career continuity. It is necessary to focus on the problems of female tour guides because the number of female tour guides is less than male ones in Turkey; tour guiding is considered as a male profession and female tour guides experience work-family conflict due to multiple roles of female tour guides and therefore they cannot pursue tour guiding as a career.
\end{abstract}

Methodology: Qualitative research method and phenomenology were used as a research design in accordance with the purpose of research. The snowball sampling method, one of the purposive sampling methods, was selected to determine the participants. Data, obtained through semi-structured interview, face-to-face and telephone interviews were evaluated with MAXQDA (demo) qualitative data analysis program. Content analysis was utilized as a data analysis strategy.

Findings: As the result of descriptive analyses, female tourist guides mostly mentioned about the sub-themes of children and spouses. It was fond that female tourist guides experienced more tension-based conflict at low level. It was determined that they experienced more family-work conflicts and family responsibilities preceded work-related responsibilities. As the result of relational analysis, it was revealed that they wanted to pursue their careers through the support of spouses who were tourist guides or worked in the tourism sector. However, some female tour guides stated that they didn't want to pursue tour guiding as a career because of having no time for children, not keeping family relations in balance and going on long term tours etc.

Originality/Value: This research is thought to contribute to the literature and the sector due to few studies on tourist guides, which especially deal with the problems of female tourist guides in terms of work-family conflict and career continuity.

Limitations: The most important limitation of the research constituted that it was only conducted on married and female tour guides, working actively in Turkey.

Implications: In researches carried out in social sciences, it is accepted that the phenomenon of "culture" is an extremely important factor affecting the research result. For this reason, it is thought that repeating the research in Western cultures where a woman is defined differently from a man may change the result of research. It is important to be employed more tour guides by travel agencies in terms of going on tours by turns and so having more time for families.

Keywords: Work-family conflict, career continuity, female tour guides.

Paper Type: Research article

\title{
Giriş
}

İş ve aile her ne kadar endüstriyel devrimle birlikte birbirinden uzaklaşmış iki kavram gibi görünse de; birbirleri üzerinde etkili olmaya devam etmektedir. Bireylerin iş ve aile yaşamları arasında denge kurmaları toplumsal yapının bozulmaması ve aynı zamanda da bireyin iş yaşamında başarılı olması açısından önem arz etmektedir. Çalışılan sektör ve örgüt yapısı ve örgüt kültürü gibi faktörlerle birlikte bireyin medeni hali, çocuk sayısı ve eşlerin çalışma durumu gibi demografik özelliklerin de iş-aile çatışması üzerinde doğrudan etkisinin bulunduğu görülmektedir. Söz konusu unsurlara bağlı olarak iş-aile çatışması yaşayan bir bireyin işten ayrılma eğilimi göstermesi yüksektir (Kara, 2018). Özellikle Cumhuriyetle birlikte Türkiye'de sosyal, ekonomik ve siyasi bir takım haklar

Demirel, N., Yumuk, Y. ve Hacıoğlu, N. (2021). İş-aile rol çatışması ve kariyer devamlılığı ilişkisi: kadın turist rehberleri üzerine bir değerlendirme / The relation between work-family conflict and career continuity: an evaluation on female tour guides 
elde ederek iş yaşamına katılan kadının (Ayoğul, 2017); eşlik ve annelik görevlenin yanı sıra iş yaşamında da aktif rol üstlenmesi erkeklere göre daha fazla iş-aile çatışması yaşamasına yol açmıştır. İnsanın insana hizmet verdiği ve dolayısıyla rekabet üstünlüğü elde etmenin daha çok insan gücüne bağlı olduğu hizmet sektöründe iş-aile çatışmasına daha sık rastlanmaktadır.

İş ve aile kaynaklı roller, özellikle çalışma koşullarının diğer sektörlerden daha ağır olduğu hizmet sektörünün bir kolu olan turizm sektöründe çalışan bireyler açısından zaman zaman birbiriyle uyumsuzluk göstermekte ve hatta çatışabilmektedir. İş-aile çatışmasına her türlü açık ve kapalı ortamlarda çalışmayı gerektiren, çalışma zamanının belli olmadığı, çalışma saatlerinin uzun olduğu ve değişkenlik gösterebildiği turist rehberliği mesleğinde de sıklıkla rastlanılmaktadır (Demirbulat, 2014). Konu ile ilgili gerçekleştirilen bazı araştırmalar kadın turist rehberlerinin mesleklerini icra ederken ailevi sorunlarla karşı karşıya kaldıklarını göstermektedir (Zengin \& diğerleri, 2014: Acun, 2016; Arslan \& Şimşek, 2018). Çalışma hayatında her geçen gün sayısı hızla artan kadınlara toplum tarafından yüklenen ev temizliği, yemek yapma ve çocuk bakımı gibi roller kadının iş hayatında gerilim yaşamasına sebebiyet vermekte (Kargiglioğlu \& Özer, 2018); mesleki başarısını olumsuz etkileyebilmektedir (Parasuraman \& Greenhaus, 2002). Bu bağlamda, araştırmanın amacı evli kadın turist rehberlerinin iş-aile rol çatışması algıları ile kariyer devamlılığı eğilimleri arasındaki ilişkiyi ortaya koymaktır.

\section{1. İş-Aile Rol Çatışması}

İş-aile çatışması, aile ve iş kaynaklı roller arasında bazı durumlarda uyumsuzluğun hissedilmesiyle birlikte ortaya çıkmaktadır. İş-aile çatışmasına göre; bir rolün (iş ya da aile) gereklerini yerine getirmek, diğer rolün (iş ya da aile) gereklerini yerine getirmeyi zorlaştırabilmektedir (Greenhaus \& Beutell, 1985). İş-aile çatışmasının ortaya çıkmasında iş baskısı daha etkili olabileceği gibi aile baskısının daha etkili olduğu durumlar da söz konusu olabilmektedir (Parasuraman \& Greenhaus, 2002). Kısacası iş-aile çatışması, iş veya aile yaşamındaki rollerin bir arada gerçekleştirilememe durumunu ifade etmektedir (Frone \& Rice, 1987).

İş-aile çatışması zaman temelli, gerilim temelli ve davranış temelli çatışma olarak üçe ayrılmaktadır. Zaman temelli çatışma bir rolün yerine getirilebilmesi için ayrılması gereken zamanın diğer rolün gereklerini yerine getirememesi durumunda ortaya çıkmaktadır (Helmy, 2018). Farklı roller üstlenen bireyin zamanın kısıtlı olması nedeniyle her bir role yeterince zaman ayıramadığ görülmektedir (Netemeyer, Boles \& McMurrian, 1996). Gerilim temelli çatışma, bireyin bir rolden kaynaklanan stres ve gerilimi diğer role yansitması durumudur (Helmy, 2018). Eş desteğinin yokluğu, eşlerin birbirlerine karşı anlayışsız olmaları ve evde küçük çocuğun varlığı gibi faktörler gerilim temelli iş-aile çatışması faktörleri arasındadır. Davranış temelli çatışma ise bir rolün gerektirdiği tutum ve davranışların diğer rolden beklenen tutum ve davranışlarla uyumlu olmamasıdır. Örneğin iş hayatında sert bir mizaca sahip olan bireyin aynı tutumu aile hayatında sergilemesi bazı sorunların yaşanmasına sebep olabilmektedir (Greenhaus \& Beutell, 1985).

Araştırmalar işle ilgili farklı faktörlerin iş-aile çatışmasına zemin oluşturduğunu ileri sürmektedir. İşin tam zamanlı olması, esnek olmayan çalışma programı, vardiya sistemi, iş güvensizliği, ağır iş yükü, iş stresi ve yöneticiden destek alamama söz konusu faktörlerden bazılarıdır (Vong \& Tang, 2017). Diğer taraftan yaşam döngüsü evresi, eş desteği, aile bağlılı̆̆ı ve çocuk bakımı gibi faktörler de iş-aile çatışmasını etkilemektedir (Gamor \& diğerleri, 2018). Cinsiyete bağlı olarak yaşanan çatışmalar ise günümüzde oldukça dikkat çekmektedir (Kara, 2018). Özellikle endüstriyel devrimin bir sonucu olarak kadın işgücünün artış göstermesi ve dolayısıyla çift gelirli çiftlerin sayılarında gözlemlenen artışla birlikte iş-aile çatışması kavramı gittikçe daha önemli hale gelmektedir (Chen, Ayoun \& Eyoun, 2018).

İş-aile çatışmasının bireysel, aileye yönelik ve örgütsel bazı olumsuz sonuçlar doğurduğunu ortaya koyan araştırmalara rastlanmaktadır. İşe devamsızlık, düşük performans, yüksek iş gücü devir

Demirel, N., Yumuk, Y. ve Hacıoğlu, N. (2021). İş-aile rol çatışması ve kariyer devamlılığı ilişkisi: kadın turist rehberleri üzerine bir değerlendirme / The relation between work-family conflict and career continuity: an evaluation on female tour guides 
Turist Rehberliği Dergisi (TURED) \& Yıl. 2021, Cilt. 4, Sayı. 1

Journal of Tour Guiding (JOTOG) \& Year. 2021, Volume. 4, Issue. 1

hızı ve iş tatminsizliği örgütlerde istenmeyen sonuçları ifade ederken; endişe, stres, depresyon, yaşam kalitesizliği, olumsuz sosyal davranışlar ve aile hayatı tatminsizliği birey ve ailenin karşı karşıya kalabileceği olumsuz durumlardır (Parasuraman \& Greenhaus, 2002; Güzel \& Özgül, 2014). Aycan \& Eskin (2005) tarafından 434 çocuklu katılımcıyla yapılan araştırmada; iş-aile çatışması ile psikolojik iyi olma hali, evliliğe yönelik tatmin ve ebeveyn rol performansı arasında negatif bir ilişkinin olduğu belirtilmektedir. Aynı araştırmada kadınların iş-aile çatışma algıları ile eş desteğinin ilişkili olduğu; erkeklerin iş-aile çatışma algıları ile eş ve kurumsal desteğin ilişkili olduğu açılanmaktadır. Chen ve çalışma arkadaşları (2018) Çin'de ve Amerika'da otel çalışanları üzerinde gerçekleştirdikleri karşılaştırmalı araştırma; Çin'de faaliyet gösteren otel işletmelerindeki kadın çalışanların iş-aile çatışması algılarının Amerika'dakilere göre daha yüksek olduğunu ve iş-aile çatışması ile işten ayrılma niyeti arasında pozitif yönde güçlü bir ilişkinin bulunduğunu göstermektedir. Yang \& Peng (2018) tarafindan Guangzhou \& Zhangjiajie'de faaliyet gösteren otel işletmelerindeki 322 kadın çalışan üzerinde gerçekleştirilen bir diğer araştırma; iş-aile çatışması algıları yüksek olan kadınların işten ayrılma niyetlerinin diğerlerine göre daha fazla olduğunu ve söz konusu kadınların iş tatmini düzeylerinin ise diğerlerine göre daha az olduğunu ortaya koymaktadır.

\section{Kariyer Devamlılı̆̆ı}

Kariyer kavramı, Fransızca kökenli olup "Bir meslekte zaman ve çalışmayla elde edilen aşama, başarı ve uzmanlık" anlamına gelmektedir (www.sozluk.gov.tr). Fransa'da,1530'larda kariyer kelimesinin "yol, yarış pisti” gibi anlamlara geldiği; 1590'larda ise "genel eylem ve hareket tarzı" anlamlarında kullanıldığı görülmektedir. 1803'ten itibaren ise "kişinin kamusal veya mesleki yaşamının seyri" şeklinde tanımlanmaktadır (www.etymonline.com). Arthur, Hall \& Lawrence (1989), kariyer teorisini tarihsel süreç içerisinde inceleyerek kariyerin aslında sadece mesleki seyirden ibaret olmadığını, insanların iş yaşamı boyunca psikolojik, sosyolojik açıdan değerlendirilmesi gerektiğini öne sürmektedir. Sosyolojik açıdan bakıldığında kariyer, bir sınıf farkı veya kademeyi ortaya koymakta, psikolojik açıdan bakıldığında ise insanların günlük yaşamları ve iş yaşamlarının ilişkisini belirlemektedir. Bununla birlikte, kariyer kavramı ekonomi, politika, coğrafya, antropoloji, tarih gibi alanlarla iç içedir (Arthur, Hall \& Lawrence, 1989).

Kariyer tanımları genel olarak erkek hiyerarşisine atfedilmekte ve yalnızca erkeğe özgü bir kavram olarak bahsedilmektedir. Kadınlardan ise annelik ve ev işleri görevlerini yerine getirmeleri beklenmektedir (Patton, 2013). 1980'lerde işgücü söz konusu olduğunda daima erkek işgücünün akla gelmesi de kariyer kavramının yalnızca erkeklere atfedilmesiyle ilgili olarak ortaya çıkan bir sonuçtur. 1980'ler sonrası ise kadın işgücünün iş hayatında yerini alması gerektiği fikrinin giderek önem kazandığı görülmektedir (White, 1995). 1990'larda kariyer kavramının geleneksel bir çerçevede irdelendiği görülse de, kadınların kariyer süreçlerinin ele alınmaya başlandığı belirtilmektedir (Patton, 2013).

Tükeltürk \& Şahin Perçin (2008)'e göre hizmetin ön planda olduğu turizm sektöründe kadın çalışanların sayısı giderek artmasına rağmen kadınlar hem otel işletmelerinde hem de seyahat acentelerinde birçok sorunla karşı karşıya kalmaktadırlar. Ayrıca turizmde kadınların iş ve aile yaşamı konusunda denge kurmasının zor olduğu belirtilmektedir. Kadınların aile yaşantısında daha fazla sorumluluk almaları onların yönetim kademelerinden veya mesleklerindeki başarılardan uzak kalmalarına sebep olabilmektedir. Kadınların yönetim kademeleri ve mesleki başarıları önündeki engellerin toplumsal rol ve ailevi sorumluluklar gibi mecburiyete veya önyargilara dayanan bir ayrımcılıktan kaynaklandığ düşünülmektedir. Kariyer engellerinin ortadan kaldırılabilmesi için çözüm önerilerinin ve stratejilerin belirlenmesi, sektörde çalışan kadınların iş performansına etki eden konularda sorun yaşamamaları için önem arz etmektedir. Birçok kadın çalışırken aile yaşantıları olumsuz etkilense de, kariyerini geliş̧irmeyi devam ettirmekte ve bunun için gereken fedakârlıkları yapabilmektedir (Tükeltürk \& Şahin Perçin, 2008).

Demirel, N., Yumuk, Y. ve Hacıoğlu, N. (2021). İş-aile rol çatışması ve kariyer devamlılığı ilişkisi: kadın turist rehberleri üzerine bir değerlendirme / The relation between work-family conflict and career continuity: an evaluation on female tour guides 
Turist Rehberliği Dergisi (TURED) \& Yıl. 2021, Cilt. 4, Sayı. 1

Journal of Tour Guiding (JOTOG) \& Year. 2021, Volume. 4, Issue. 1

İş yaşamına dâhil olan kadınların, iş ve ev yaşamında motivasyonlarının ve verimliliklerinin düşmesine sebep olan sorun, "iş kadını" ve "ev kadını" rollerini aynı anda üstlenmeleridir. Eşi olan veya olmayan evli kadınların çoklu sorumlulukları üstlenmelerinden kaynaklanan sorunları daha yüksek düzeyde yaşadıkları tespit edilmiş̧ir (Acuner, 2019). Çoğu toplumda çocuğun bakımı ve eğitimi konusunda kadına ihtiyaç duyulmakta ve anneliğe özel bir anlam atfedilmektedir. Kadın çalışma yaşamına katılmaya karar verdiğinde kariyer ve aile arasında denge kurmaya çalışmakta ve birçok rol üstlenmektedir (Adak, 2007). Kadınlar erkeklerden farklı olarak evleriyle ve çocuklarıyla ilgilenmek zorunda olduğunu hissetmekte ve kariyerlerini geliştirmek için daha fazla zaman harcamaktadırlar. Bununla birlikte cinsiyet ayrımcıllğı ve iş-aile dengesinin kurulması gibi faktörler turizm endüstrisinin emek yoğun özelliği ile birleştiğinde kadınların kariyer gelişiminin etkilendiği görülmektedir (Tükeltürk \& Şahin Perçin, 2008).

Özellikle dini kurallara bağlı olarak yaşayan toplumlardaki değerler, kadının eş, anne ve ev hanımı olma rolünü vurgulamakta, turist rehberi olarak çalışan kadının evden uzak yaşaması veya çalışması sonucu aile yaşamında olumsuz etkilenebileceği düşüncesini benimsemektedir (Masadeh \& diğerleri, 2018). Buna göre turist rehberliği mesleği uzun çalışma saatlerini, uzun turları, aktif bir yaşamı gerekli kıldığından iş aile yaşamına bağlı olarak kariyeri devam ettirme konusunda bazı sorunlara neden olabilmektedir.

\section{3. İş- Aile Rol Çatışması ve Kariyer Devamııı̆ı̆ı İlişsisi}

İş- aile çatışması ve kariyer devamlığı konusunu doğrudan ele alan araştırmaların sayısı yeterli olmamakla birlikte; turizm alan yazınında iş-aile çatışması ile işten ayrılma niyeti ilişkisini inceleyen benzer bazı araştırmalar bulunmaktadır (Eşitti, 2018; Savaşkan \& Kulualp, 2019; Seçilmiş \& Kılıç, 2017). Ancak anne, eş ve iş kadını olarak üstlendiği birden fazla rol nedeniyle kadınların erkeklere göre daha fazla iş-aile çatışması yaşadıkları gözlenmektedir. Ezzedeen \& Ritchey (2009) yönetici kadınlar üzerine yaptıkları araştırmada çocuklu kadınların kariyerlerinin yavaşladığı, bazılarının erkekleri yakalamak için daha fazla çalıştığı, bazılarının ise yöneticilik kariyerine son verdiği sonucuna ulaşmışlardır. Kadının hayatında evlilik ve çocuk sahibi olma gibi dönemlerde işaile çatışmasının artacağı ve en küçük çocuğun büyümesiyle bu çatışmanın azalacağı kabul edilmektedir (Altıok Gürel, 2018). Hizmet sektörü içerisinde yer alan turizmde sektörel yapıdan kaynaklı olarak iş-aile çatışmasının olası sonuçlarına daha çok rastlanmaktadır. Kulualp \& Savaşkan (2019) İstanbul'da faaliyet gösteren otel işletmelerindeki kadın işgörenlerin iş-aile çatışma düzeylerini belirlemek amacıyla gerçekleştirdikleri araştırmada; kadın işgörenlerin çalıştıkları departman ve çalışma sürelerine bağlı olarak iş-aile çatışması düzeylerinin farklılık gösterdiğini ortaya koymuştur. Araştırma sonucu, kadın işgörenlerin işletmedeki çalışma süreleri arttıkça iş-aile çatışma düzeylerinin azaldığını ve mutfak departmanında çalışan kadınların söz konusu çatışma düzeylerinin diğer departmanlara göre daha az olduğunu göstermektedir.

Doğan, Üngüren \& Kesgin (2010), turist rehberliği mesleğini bekâr kadınların daha iyi icra edebileceğini ve bunun yanı sıra turist rehberliği mesleğini icra ederken aldatma, boşanma ve benzeri ailevi sorunların ortaya çıkabileceğini ortaya koymuşlardır. Ancak evlilik turist rehberliği mesleğinin önünde bir engel olarak görülmemektedir. Bir kadın ev hayatında ve iş hayatında aynı rolleri üstlenmemekte her birinde farklı rollere bürünmektedir. Bu roller arasında denge kurulmadığında ise iş aile çatışması yaşanmaktadır. Kadınların erkeklerden daha fazla iş-aile çatışması yaşamaları, toplumun ev işleri ve çocuk bakımı gibi sorumlulukları kadının birincil görevi olarak kabul etmesinden kaynaklanmaktadır. Kadınların aile ile ilgili sorumlulukları birinci planda tutmaları başarılı bir kariyere sahip olmalarını; başarılı bir kariyere sahip olmaları ise iyi bir eş ve anne olmalarını engellemektedir (Ayoğul, 2017). Ancak turist rehberli üzerine gerçekleştirilen bir araştırmada; turist rehberleri, mesleklerinin kendilerine zaman ayırma konusunda engel teşkil etmediğini, mesleki sorumlulukların ailevi sorumlulukların önüne geçmediğini düşünmektedirler. Ayrıca meslekleri dolayısıyla özel hayatlarına dair planlarını değiştirmek veya ertelemek zorunda

Demirel, N., Yumuk, Y. ve Hacıoğlu, N. (2021). İş-aile rol çatışması ve kariyer devamlılığı ilişkisi: kadın turist rehberleri üzerine bir değerlendirme / The relation between work-family conflict and career continuity: an evaluation on female tour guides 
Turist Rehberliği Dergisi (TURED) \& Yıl. 2021, Cilt. 4, Sayı. 1

Journal of Tour Guiding (JOTOG) \& Year. 2021, Volume. 4, Issue. 1

kalmadıklarını, aile içi tartışma yaşamadıklarını belirtmektedirler (Demirbulat, 2014). Araştırmada ele alınan iş aile rol çatışması ve kariyer devamlılığ i ilişkisi hem alan yazın hem de mülakatlar sonucu elde edilen nitel veri doğrultusunda incelenerek detaylandırılmaktadır.

\section{Yöntem}

Araştırmada nitel araştırma yönteminden yararlanılmıştır. Nitel araştırma, sosyal gerçekliğin ve insan davranışlarının arkasında yatan nedenleri anlamaya çalışan; görüşme, gözlem ve doküman analizi gibi nitel veri toplama tekniklerinden yararlanan araştırmalardır (Gürbüz ve Şahin, 2014). Nitel araştırma dünyadaki gözlemcinin yerini tespit eden konumlandırılmış bir aktivitedir ve dünyayı görünür hale getiren bir dizi yorumlayıcı, materyal uygulamalarından oluşmaktadır. Bu uygulamalar dünyayı; alan notları, mülakatlar, konuşmalar, fotoğraflar, kayıtlar ve araştırmacı günlüklerini içeren bir temsiller serisine dönüştürmektedir. Nitel araştırma; varsayımlarla bireyler veya grupların sosyal sorunlarına ya da insan sorununa atfettikleri anlamlara değinen ve araştırma problemlerinin incelenmesini içeren yorumlayıcı/kuramsal çerçevelerin kullanımı ile başlamaktadır (Creswell, 2018). Araştırma deseni olarak fenomenolojik (betimsel fenomenoloji) desen belirlenmiştir. Fenomenolojik desen tek bir kavram veya düşüncenin ifade edildiği, araştırılacak bir fenomene vurgu yapmaktadır. Birkaç birey tarafından deneyimlenen bir fenomenin (olgu) derinlemesine anlaşılmasını sağlamaktadır (Creswell, 2018). Bu araştırmanın fenomenleri ise kariyer devamlılığı ve iş aile çatışması değişkenleridir.

Veri toplama aracı olarak görüşme/mülakat ve doküman inceleme tekniği seçilmiştir. Kozak (2014), mülakat tekniğinin kullanılacağı nitel araştırmalarda örneklem sayısının belirlenmesinde, toplanan verinin kalitesi ve tekrar edilmesi ilkesi önemli olmakla birlikte, 20-30 arası görüşmenin yeterli olacağını kabul etmektedir. Araştırmanın amacına yönelik oluşturulan sorular doküman inceleme yoluyla hazırlanmış, 2 profesyonel turist rehberi (kadın) ve turizm alanında çalışan 3 akademisyenden uzman görüşü alınmıştır. Böylelikle sorular gözden geçirilerek yarı yapılandırılmış görüşme tekniği ile veri toplanmıştır. Görüşme sözlü iletişim yoluyla insanları ve onlarla ilişkili durumları anlamaya çalışan bir veri toplama tekniğidir (Gürbüz \& Şahin, 2014). Türkiye'de eylemlieylemsiz kadın turist rehberi sayıs 3668 olmakla birlikte 2347 eylemli kadın turist rehberi araştırmanın evrenini oluşturmaktadır (www.tureb.org.tr). Araştırmada telefonla ve yüz yüze görüşmeyle 21 katılımcıya ulaşılmıştır. Katılımcılarla görüşmeler 25 ve 45 dakika arasında sürmüştür.

Örneklemin belirlenmesinde amaçlı ve kartopu örnekleme yöntemlerinden yararlanılmıştır. Amaçlı örneklem/yargılayıcı örnekleme yönteminde katılımcılar belirlenirken bazı gruplarla ilgili özel bilgilere ya da deneyimlere gerek duyulmaktadır. Kartopu/zincirleme örnekleme yönteminde ise ilgilenilen özelliğe sahip birkaç kişi belirlenerek görüşme yapılmakta ve bu kişilerden benzer özelliklere sahip başka kişilere yönlendirmeleri istenilmekte ve katılımcı zinciri oluşturulmaktadır (Berg \& Lune, 2015). Evli ve kadın turist rehberlerinin örneklemi temsil ettiği araştırmada veri analizinde içerik analizinden faydalanılmıştır. Genel anlamda içerik analizi, çeşitli yazılı dokümanlar, fotoğraflar, videolar ve ses kayıtlarını da içeren ve insanlar arasında gerçekleşen çeşitli iletişim şekillerinde uygulanabilmektedir (Berg \& Lune, 2015). Araştırmanın ana ve alt temalarının belirlenmesinde öncelikle kapalı kod sistemi ile alan yazın doğrultusunda oluşturulan ana ve alt temalar belirlenmiştir. Ardından sahadan gelen veri ve açık kod sistemiyle ana temalar ve alt temalar yeniden değerlendirilmiş̧ir. Nitel araştırmalarda güvenirlik genellikle veri setlerindeki birden fazla kodlayıcının cevaplarındaki kararlılık anlamına gelmektedir (Creswell, 2018). Araştırmanın güvenirliğini sağlamak için alan uzmanlarına danışma stratejisinden yararlanılmış ve kodlayıcılar arası uzlaşma sağlanmıştır.

Demirel, N., Yumuk, Y. ve Hacıoğlu, N. (2021). İş-aile rol çatışması ve kariyer devamlılığı ilişkisi: kadın turist rehberleri üzerine bir değerlendirme / The relation between work- family conflict and career continuity: an evaluation on female tour guides 
Turist Rehberliği Dergisi (TURED) \& Yıl. 2021, Cilt. 4, Sayı. 1

Journal of Tour Guiding (JOTOG) \& Year. 2021, Volume. 4, Issue. 1

\section{Bulgular}

İş-aile çatışması ve kariyer devamlılığı ilişkisini ortaya koymaya yönelik olarak 21 kadın turist rehberiyle yüz yüze ve telefonla gerçekleştirilen görüşmeler sonucu elde edilen verinin analizine ilişkin sonuçlar bu başlık altında yer almaktadır. Bu kapsamda öncelikle kadın turist rehberlerine ilişkin demografik bilgilere yer verilmekte, daha sonra ana tema ve alt temalara yönelik açıklamalarda bulunulmaktadır. Betimsel ve ilişkisel olan bu araştırmada bulguları ortaya koyabilmek için kelime frekans analizi ve kod ilişkiler tarayıcısı vasıtasıyla kod teori modeli kullanılmıştır. Bununla birlikte katılımcıların görüşlerine ilişkin ifadelere yer verilmiştir.

Tablo 1'de katılımcıların demografik bilgilerine yer verilmektedir. Katılımcilarla yapılan görüşmelerde katılımcılara Tablo 1'de görüldüğü gibi K1, K2, K3,..K21 şeklinde kodlar verilmiş ve alıntılar bu kodlara göre aktarılmıştır.

Tablo 1

Katılımcılara İlişkin Demografik Bilgiler

\begin{tabular}{|c|c|c|c|c|c|c|c|}
\hline Katılımcı & Yaş & Eğitim & $\begin{array}{l}\text { Çocuk Sahibi } \\
\text { Olma Durumu }\end{array}$ & $\begin{array}{l}\text { Çalışma } \\
\text { Şekli }\end{array}$ & $\begin{array}{c}\text { Mesleki } \\
\text { Deneyim }\end{array}$ & Eşinin Mesleği & $\begin{array}{c}\text { Yaklaşık Aylık } \\
\text { Kazanç (TL) }\end{array}$ \\
\hline K1 & $26-35$ & Lisans & Var & Serbest & $\begin{array}{l}10 \text { yil ve } \\
\text { üzeri }\end{array}$ & $\begin{array}{l}\text { Özel Sektör } \\
\text { Çalıșanı }\end{array}$ & 3000 \\
\hline K2 & $26-35$ & Lisans & Yok & Serbest & $7-9$ y1l & $\begin{array}{l}\text { Özel Sektör } \\
\text { Çalışanı }\end{array}$ & 4500 \\
\hline K3 & $26-35$ & Ön lisans & Var & Serbest & $7-9$ y1l & $\begin{array}{l}\text { Özel Sektör } \\
\text { Çalışanı }\end{array}$ & 9000 \\
\hline K4 & $36-45$ & Lisans & Var & Serbest & $\begin{array}{c}10 \text { yll ve } \\
\text { üzeri }\end{array}$ & Turist Rehberi & 7000 \\
\hline K5 & $26-35$ & Lisans & Var & Serbest & $\begin{array}{l}10 \text { yil ve } \\
\text { üzeri }\end{array}$ & Turist Rehberi & 3000 \\
\hline K6 & $36-45$ & Lisans & Var & Serbest & $\begin{array}{l}10 \text { yil ve } \\
\text { üzeri }\end{array}$ & $\begin{array}{l}\text { Özel Sektör } \\
\text { Çalışanı }\end{array}$ & 4500 \\
\hline K7 & $26-35$ & Lisans & Var & Serbest & $\begin{array}{c}10 \text { y1l ve } \\
\text { üzeri }\end{array}$ & Turist Rehberi & 10000 \\
\hline K8 & $26-35$ & Lisansüstü & Yok & Serbest & 7-9 y1l & Turizm Sektörü & 10000 \\
\hline K9 & $26-35$ & Lisans & Var & $\begin{array}{c}\text { Acenteye } \\
\text { Bağl1 }\end{array}$ & $\begin{array}{l}10 \text { yıl ve } \\
\text { üzeri }\end{array}$ & Turist Rehberi & 3000 \\
\hline K10 & $\begin{array}{l}46 \text { ve } \\
\text { üzeri }\end{array}$ & Ön lisans & Var & Serbest & $\begin{array}{l}10 \text { yil ve } \\
\text { üzeri }\end{array}$ & $\begin{array}{l}\text { Özel Sektör } \\
\text { Çalışanı }\end{array}$ & 8000 \\
\hline K11 & $26-35$ & Lisans & Var & Serbest & $4-6$ y1l & $\begin{array}{c}\text { Özel Sektör } \\
\text { Çalışanı* }\end{array}$ & 7000 \\
\hline K12 & $26-35$ & Lisans & Yok & Serbest & $\begin{array}{c}10 \text { yll ve } \\
\text { üzeri }\end{array}$ & Turist Rehberi & 8000 \\
\hline K13 & $26-35$ & Lisans & Var & Serbest & $\begin{array}{l}10 \text { yil ve } \\
\text { üzeri }\end{array}$ & Turist Rehberi & 7500 \\
\hline K14 & $36-45$ & Lisans & Var & Serbest & $\begin{array}{l}10 \text { y1l ve } \\
\text { üzeri }\end{array}$ & $\begin{array}{c}\text { Turizm Sektörü } \\
\text { Çalışanı }\end{array}$ & 4500 \\
\hline K15 & $\begin{array}{l}46 \text { ve } \\
\text { üzeri }\end{array}$ & Lisans & Var & Serbest & $\begin{array}{l}10 \text { y1l ve } \\
\text { üzeri }\end{array}$ & Turist Rehberi & 4500 \\
\hline K16 & $36-45$ & Lisans & Var & Serbest & $\begin{array}{l}10 \text { yil ve } \\
\text { üzeri }\end{array}$ & $\begin{array}{c}\text { Özel Sektör } \\
\text { Çalışanı* }\end{array}$ & 10000 \\
\hline K17 & $36-45$ & Lisans & Yok & Serbest & 7-9 y1l & $\begin{array}{c}\text { Özel Sektör } \\
\text { Calıșanı* }\end{array}$ & 8000 \\
\hline K18 & $26-35$ & Ön lisans & Var & Serbest & 7-9 y1l & Turizm Sektörü & 4000 \\
\hline K19 & $26-35$ & Lisans & Var & Serbest & 7-9 y1l & $\begin{array}{c}\text { Kamu Sektörü } \\
\text { Çalıșanı }\end{array}$ & 4500 \\
\hline K20 & $26-35$ & Lisans & Var & Serbest & $7-9$ y1l & $\begin{array}{l}\text { Özel Sektör } \\
\text { Çalışanı* }\end{array}$ & 4500 \\
\hline K21 & $36-45$ & Lisans & Var & Serbest & $\begin{array}{l}10 \text { y1l ve } \\
\text { üzeri }\end{array}$ & Turist Rehberi & 10000 \\
\hline
\end{tabular}

*Tabloda "özel sektör çalışanı" olarak belirtilen kișiler turizm sektöründeki herhangi bir işletmeye bağlı olarak çalışmamaktadır. "Turizm sektörü çalışanı" olarak belirtilen kişiler ise turist rehberliği haricindeki diğer turizm işletmelerindeki mesleklere mensuptur.

Demirel, N., Yumuk, Y. ve Hacıoğlu, N. (2021). İş-aile rol çatışması ve kariyer devamlılığı ilişkisi: kadın turist rehberleri üzerine bir değerlendirme / The relation between work-family conflict and career continuity: an evaluation on female tour guides 
Turist Rehberliği Dergisi (TURED) \& Yıl. 2021, Cilt. 4, Sayı. 1

Journal of Tour Guiding (JOTOG) \& Year. 2021, Volume. 4, Issue. 1

Araştırmaya katılan kadın turist rehberlerinin büyük çoğunluğunun 26-35 yaş aralığında olduğu ve daha çok lisans mezunu oldukları belirtilmektedir. Çocuk sahibi olma durumlarına bakıldığında, sadece 4 kadının çocuk sahibi olmadığı, 17 kadının ise bir veya iki çocuğa sahip oldukları görülmektedir. Kadın turist rehberleri daha çok serbest çalışmayı tercih etmektedirler. Genel olarak 10 yıl ve üzeri mesleki deneyime sahip olan kadın turist rehberlerinin işlerinde profesyonel olduklarını söylemek mümkündür. Kadın turist rehberlerinin eşleri genel olarak turizm sektöründe çalı̧̧maktadırlar veya kendileri gibi turist rehberliği mesleği icra eden bireylerdir. Gelir düzeylerine bakıldığında tura sık çıkma veya çıkmama durumuna bağlı olarak kişiden kişiye değişkenlik gösterdiği ortaya çıkmaktadır.

Tablo 2.

Ana Tema ve Alt Temalara İlişkin Açıklamalar

\begin{tabular}{|c|c|c|}
\hline Ana Temalar & Alt Temalar & Açıklamalar \\
\hline \multirow{4}{*}{ İş- Aile Çatışması } & $\begin{array}{l}\text { Zaman Temelli } \\
\text { Çatışma }\end{array}$ & $\begin{array}{l}\text { Kadın turist rehberlerinin tura çıtıkları zaman diliminde aile ile } \\
\text { ilgili rollerinin gereklerini yerine getirememeleri durumunu ifade } \\
\text { etmektedir. }\end{array}$ \\
\hline & $\begin{array}{l}\text { Duygusal } \\
\text { Çatışma }\end{array}$ & $\begin{array}{l}\text { Kadın turist rehberlerinin tura çıktıklarında aile ile ilgili } \\
\text { yaşadıkları özlem, vicdan gibi duygusal süreçleri ifade } \\
\text { etmektedir. }\end{array}$ \\
\hline & $\begin{array}{l}\text { Davranışsal } \\
\text { Çatışma }\end{array}$ & $\begin{array}{l}\text { Turist rehberliği ile ilgili rolün gerektirdiği tutum ve davranışların } \\
\text { aile ile ilgili rolden beklenen tutum ve davranışlarla uyumlu } \\
\text { olmamasıdır. }\end{array}$ \\
\hline & $\begin{array}{l}\text { Gerilim Temelli } \\
\text { Çatışma }\end{array}$ & $\begin{array}{l}\text { Kadın turist rehberlerinin turist rehberliği rolünden kaynaklanan } \\
\text { stres ve gerilimi aileye yansıtması durumudur. }\end{array}$ \\
\hline \multirow{8}{*}{ Aile-İş Çatışması } & Eş & $\begin{array}{l}\text { Kadın turist rehberlerinin eşlerinin mesleklerini destekleme veya } \\
\text { desteklememe durumunu ifade etmektedir. }\end{array}$ \\
\hline & Çocuk-Çocuklar & $\begin{array}{l}\text { Kadın turist rehberlerinin çocuk veya çocuklarını ifade } \\
\text { etmektedir. }\end{array}$ \\
\hline & $\begin{array}{l}\text { Geniş Aile ve } \\
\text { Akrabalar }\end{array}$ & $\begin{array}{l}\text { Kadın turist rehberlerinin anne, baba, kardeşlerine ayırdıkları } \\
\text { vakti ve geniş ailede gerçekleşen düğ̈̈n, cenaze, bayram vb. } \\
\text { etkinlikleri ifade etmektedir. }\end{array}$ \\
\hline & Günübirlik Tur & $\begin{array}{l}\text { Kadın turist rehberlerinin yaşadıkları yerlerde çıktıkları turları } \\
\text { ifade etmektedir. }\end{array}$ \\
\hline & Anadolu Turu & Gap, Karadeniz gibi uzun süreli çıkılan turları ifade etmektedir. \\
\hline & Ailevi Aktivite & $\begin{array}{l}\text { Çekirdek veya geniş aile ile birlikte geçirilen zamanı ifade } \\
\text { etmektedir. }\end{array}$ \\
\hline & Maddi Kazanç & $\begin{array}{l}\text { Tur karşılığında aldıkları günlük, aylık, yıllık ücreti ifade } \\
\text { etmektedir. }\end{array}$ \\
\hline & $\begin{array}{l}\text { Kariyeri Devam } \\
\text { Ettirme }\end{array}$ & $\begin{array}{l}\text { Turist rehberliği mesleğinden genel anlamda memnun olma ve bu } \\
\text { mesleği gelecekte de yapmayı isteme durumudur. }\end{array}$ \\
\hline $\begin{array}{l}\text { Kariyer } \\
\text { Devamlılığ1 }\end{array}$ & $\begin{array}{l}\text { Kariyeri Devam } \\
\text { Ettirmeme }\end{array}$ & $\begin{array}{l}\text { Turist rehberliği mesleğinden memnun olmama ve bu mesleği } \\
\text { kısa bir süre sonra içerisinde bırakma ve gelecekte yapmama } \\
\text { niyetine sahip olma durumudur. }\end{array}$ \\
\hline
\end{tabular}

Tablo 2'de alan yazın doğrultusunda oluşturulan ana ve alt temalara sahadan gelen veril ile eklemeler yapılmış ana ve alt temalar geliştirilmiştir. Tümdengelimsel ve tümevarımsal yöntemlerle elde edilen ana ve alt temalar kadın turist rehberlerinin yaşadıkları durumlar doğrultusunda açıklanmıştır.

Demirel, N., Yumuk, Y. ve Hacıoğlu, N. (2021). İş-aile rol çatışması ve kariyer devamlılığı ilişkisi: kadın turist rehberleri üzerine bir değerlendirme / The relation between work-family conflict and career continuity: an evaluation on female tour guides 


\section{IIIIII $\odot$}

Turist Rehberliği Dergisi (TURED) \& Y1l. 2021, Cilt. 4, Sayı. 1

Journal of Tour Guiding (JOTOG) \& Year. 2021, Volume. 4, Issue. 1

\section{Şekil 1}

Kelime Frekanslarına İlişkin Kelime Bulutu

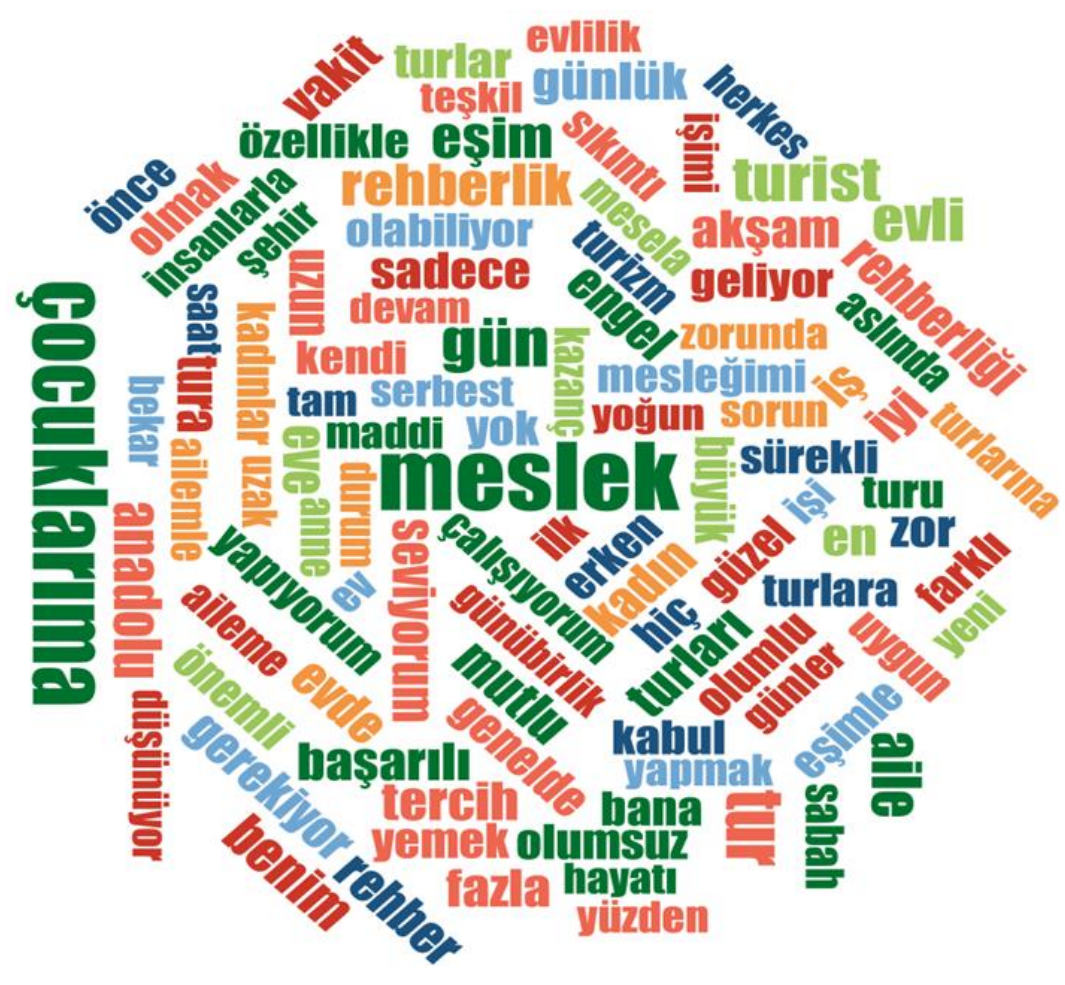

Betimsel bulguları ortaya koyabilmek için kelime frekans analizi ile kelime bulutu oluşturulmuştur. İş-aile çatışması veya aile-iş çatı̧̧ması ve kariyer devamlılı̆̆ değişkenlerinin anahtar kavramları ortaya çıkarılmıştır. Bunun için MAXQDA (demo) yazılımının MAXDicto sekmesi kullanılmıştır. Araştırmaya katılan 21 kişinin tüm ifadeleri listelenmiş ve sözcüksel taramaya tabi tutulmuştur. Türkçe'nin sondan eklemeli bir dil olması dolayısıyla bazı kelimeler (çocuğum, çocuğuma, çocuklarım, çocuklarıma, çocuklar vb.) birleştirilmiştir. Elde edilen sonuçlar içerisinde hariç listesi (mesela, ve, de, dolayısıyla, gibi, her, bile, şey, gibi kelimelerin bulunduğu liste) oluşturulmuştur. Buna göre 13983 kelime frekansı ile 100 kelime grubu tespit edilmiştir. Kelime grubuna ilişkin kelime bulutuna Şekil 1'de yer verilmektedir.

Şekil 1'de verilen kelime bulutunda, en çok tekrarlananlar kelimeler; çocuklarıma (106), meslek (100), rehberlik (100), tur (98), gün (52), turist (49), aile (44), evli (43), Anadolu (41), eşim (38), eve (34), tercih (34), mutlu (32), kadın (31), başarılı (30) kez tekrarlanmıştır. Bu durumda, evli kadın turist rehberlerinin en çok çocukları hakkında konuştukları söylenebilir.

Araştırma kapsamında 3 ana tema ve 13 alt tema belirlenmiştir. Tablo 3'te bu ana ve alt temalar verilmiş olup kariyer devamlılı̆̆ ana temasına ilişkin 60 kodlama, aile-iş çatışması ana temasına iliş̧kin 150 kodlama ve iş- aile çatışması ana temasına ilişskin 59 kodlama yapılmıştır. Frekans sonuçlarına göre kadın turist rehberlerinin genel olarak kariyerlerini devam ettirme eğilimi gösterdikleri ortaya çıkmaktadır. Araştırmada kadın turist rehberlerinin genel olarak ailelerini tercih ettikleri, özellikle çocuklarının ihtiyaçları, okul yaşamı, duyguları ve beklentilerinin anne olan kadın turist rehberinin önceliği olduğu sonucuna varılmıştır. Bu sonuca ilişkin kadın turist rehberlerinin ifadeleri şu şekildedir;

Demirel, N., Yumuk, Y. ve Hacıoğlu, N. (2021). İş-aile rol çatışması ve kariyer devamlılığı ilişkisi: kadın turist rehberleri üzerine bir değerlendirme / The relation between work- family conflict and career continuity: an evaluation on female tour guides 
Turist Rehberliği Dergisi (TURED) \& Yıl. 2021, Cilt. 4, Sayı. 1

Journal of Tour Guiding (JOTOG) \& Year. 2021, Volume. 4, Issue. 1

“...Anne olarak rahat çalışmıyorum, ailem olmasaydı çok acayip paralar kazanmış, dünyanın birçok yerini gezmiş olurdum belki ama iki küçük meleğe annelik yapma hazzını asla yaşayamazdim. " (K1)

“...Bebeğimden önce en önemli şey işimdi ancak şimdi bebeğim ve ihtiyaçlarl her şeyden önce geliyor. Kararlar değişebiliyormuş. Aile çok önemli bir kurum. ”(K3)

“...Mesleği sürdürmek çocuk sahibi olup olmamanıza göre değişiyor. Çocuklu bir anne belli bir süre ara vermek zorunda kallyor. "(K8)

Tablo 3

Ana Temalar, Alt Temalar ve Kod Sayısına İlişkin Kod Sistemi

\begin{tabular}{lc}
\multicolumn{1}{c}{ Kod Sistemi } & Frekans \\
\hline Kariyer Devamlıı̆̆ğ & 60 \\
Kariyeri Devam Ettirme & 42 \\
Kariyeri Devam Ettirmeme & 18 \\
Aile-İş̧ Çatışması & 150 \\
Eş & 38 \\
Çocuk-Çocuklar & 36 \\
Geniş Aile ve Akrabalar & 9 \\
Ailevi Aktivite & 7 \\
Günübirlik Tur & 17 \\
Anadolu Turu & 27 \\
Maddi Kazanç & 16 \\
İş-Aile Çatı̧ması & 59 \\
Zaman Temelli Çatışma & 20 \\
Duygusal Çatışma & 8 \\
Davranışsal Çatışma & 10 \\
Gerilim Temelli Çatış̧ma & 21 \\
TOPLAM & 269 \\
\hline
\end{tabular}

Şekil 2'de ana tema ve alt temalara ilişkin ilişkisel model verilmektedir. Bu modelde ilişkisel oklar üzerindeki sayılar iki ana tema veya alt tema arasındaki ilişkinin frekansı (en az 2 ilişkisi olanlar) gösterilmektedir. İlişkisel kodlama yapılırken "iş-aile veya aile-iş çatışması hangi olumsuzluklara bağlı olarak gerçekleșmiștir ve bu durum kariyer devamlılığına nasıl yansımıștır" sorusu göz önünde bulundurulmuştur. Fakat kariyeri devam ettirme olumlu bir durum olmakla birlikte genellikle eş ve maddi kazanç alt temasıyla ilişkilendirilmiştir. Kariyeri devam ettirme veya kariyeri devam ettirmeme diğer ana ve alt temalar ile ilişkilendirilmiștir. Buna göre kariyeri devam ettirme isteği turizm sektöründe çalışan veya turist rehberi olan bir eşe bağlı oluşmaktadır. Kadın turist rehberlerinin buna yönelik ifadeleri şu şekildedir;

“...Eşim rehber olmasaydı çocuktan sonra muhtemelen ben unutulup gidecektim. 2 yıl ortallkta görünmüyorum çocuktan dolayı, bir turist rehberiyle evli olmasaydım kesinlikle çok nankör bir sektör unutulup giderdim." (K7)

“...Anadolu turuna çıkan bayanlar için evliliği yürütmenin zor olduğunu düşünüyorum. Bir hafta evinden uzaklaştığ için. Evli insanların Anadolu turuna çıkmalarını pek doğru bulmuyorum açıkçası. Ya da aynı meslekten olurlarsa mantıklı olacağını düşünüyorum” (K2)

“...Eșim de turizmci. O yüzden mesleğime saygıyla yaklaşıyor. Genellikle yakınlarımdan sikıntı yaşayanlar oluyor. Özellikle eşlerden biri turizmci değilse büyük problemlere neden oluyor. Hatta evlilikleri bu meslekten dolayı biten birçok kişiyi tanıyorum." (K8)

Demirel, N., Yumuk, Y. ve Hacıoğlu, N. (2021). İş-aile rol çatışması ve kariyer devamlılığı ilişkisi: kadın turist rehberleri üzerine bir değerlendirme / The relation between work-family conflict and career continuity: an evaluation on female tour guides 


\section{IIIII) $\odot$}

Turist Rehberliği Dergisi (TURED) \& Y1l. 2021, Cilt. 4, Sayı. 1

Journal of Tour Guiding (JOTOG) \& Year. 2021, Volume. 4, Issue. 1

“...Eșim olmasaydı ben rehber olmazdım. O beni teşvik etti. Onunla ilk apranti olarak çılktım. Evlenmeseydim seyahat etme zorunluluğundan dolayı göçebe bir hayat geçirecektim.” (K14)

“...Ĕ̈er eşim turist rehberi olmasaydı zor bir evliliğim ve başarısız bir meslek hayatım olurdu. Ya da bırakırdım mesleği başka bir meslek yapardım galiba. ”(K18)

\section{SSekil 2}

İş-Aile Çatışması ve Kariyer Devamlılı̆̆ İlişkisine Yönelik Kod Teori Modeli

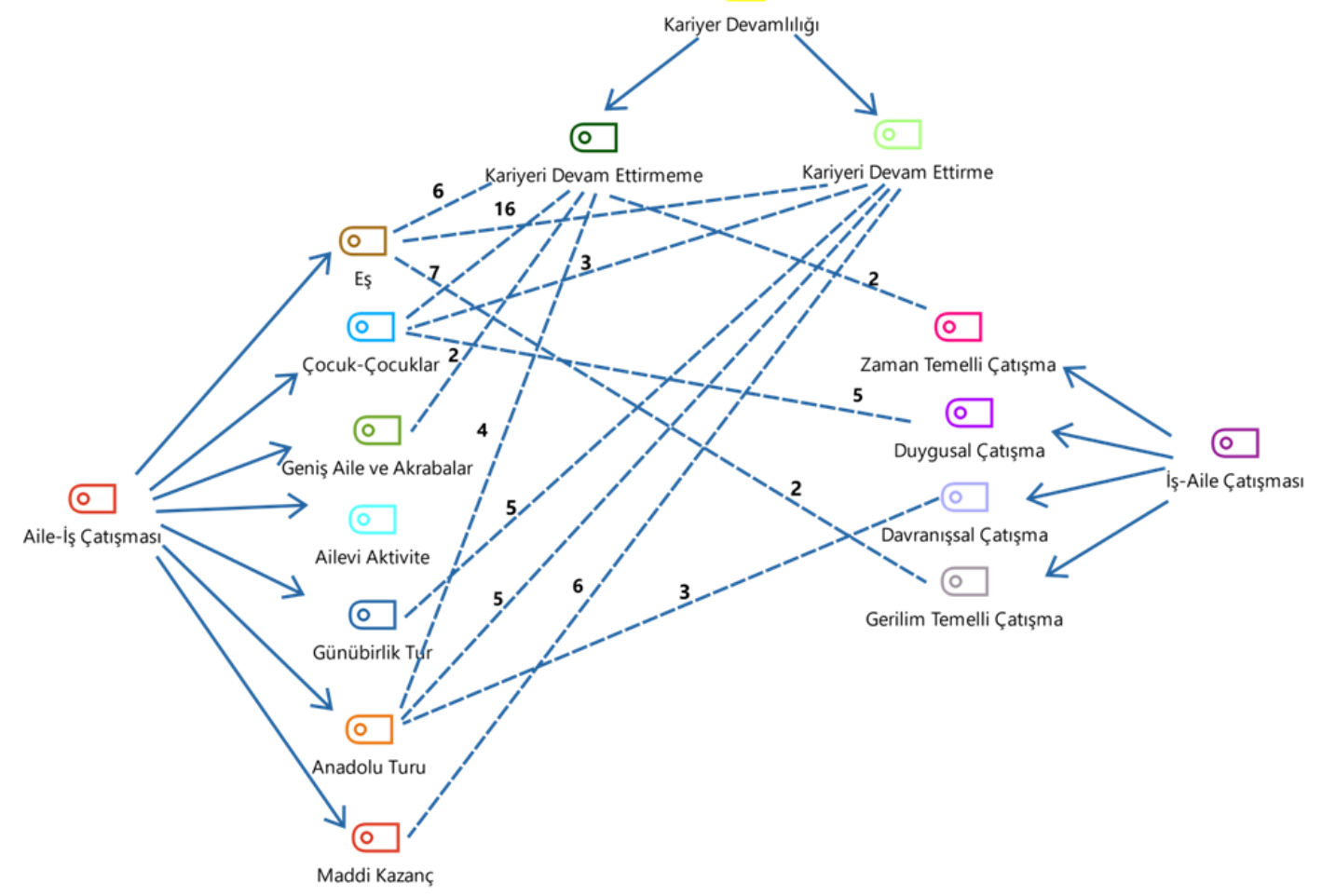

Kariyeri devam ettirme maddi kazanca bağlı bir motivasyon olarak gelişmektedir. Kadın turist rehberlerine göre maddi kazancı olmayan bir iş için aileden ve çocuklardan uzak kalmak, Anadolu turlarına çıkmak mantıklı değildir. Maddi kazancı düşünmeyen ve ailesine zaman ayırmak isteyen kadın turist rehberleri ise günübirlik turları tercih etmektedir. Bu düşünceyi destekleyen ifadeler şu şekildedir;

“...Eskiden tercihim günlük turlardı. Ama şimdi Gap, Karadeniz her türlü turlara çıkıyorum. Bundaki motivasyon maddi kazanç." (K10)

“...Mesleğimin maddi ve manevi olarak beni tatmin ettiğini söyleyebilirim. Bu sebeplerden ötürü sağlığım müsaade ettiği sürece mesleğime devam etmeyi istiyorum.” (K11)

“...Ailemi ön planda tuttuğum için günlük turlart yapıyorum....Maddi kazancı düşünürsem Anadolu turların tercih edebilirdim." (K14)

“...Anadolu turlarına çıkmamdaki ana sebep maddi kazanç. Oğlak burcuyum materyalistim. Ailemden uzak kalacaksam bunun bana çok büyük bir getirisi olmalı.”(K21)

Demirel, N., Yumuk, Y. ve Hacıoğlu, N. (2021). İş-aile rol çatışması ve kariyer devamlılığı ilişkisi: kadın turist rehberleri üzerine bir değerlendirme / The relation between work-family conflict and career continuity: an evaluation on female tour guides 
Turist Rehberliği Dergisi (TURED) \& Yıl. 2021, Cilt. 4, Sayı. 1

Journal of Tour Guiding (JOTOG) \& Year. 2021, Volume. 4, Issue. 1

Kariyerini devam ettirmek istemeyen kadın turist rehberlerinin bu konudaki en önemli sebebi çocuklardır. Anne olmak kadın turist rehberlerine göre çok kutsal ve önemli bir vasıftır. Bu nedenle kadın turist rehberleri, işlerinden ziyade çocuklarını ve ailelerini tercih etmektedirler. Bu konudaki görüşler şu şekildedir;

“...Rehberlik yapmayı pek düşünmüyorum. Küçük kızım da büyüyünce belki yapabilirim ya da Kapadokya'da kalıp günlük turlara çıkabilirim. Daha çok kariyer odakliydım ama bazen çocuklardan dolayı ertelemek gerekebiliyor." (K13)

“...Genellikle nisan başlarında çocuğumun doğum gününden dolayı kesinlikle tur kaçırıyorum. Böyle sıkıntılar oluyor genelde, tabi ki çocuğu tercih ediyorum ama yine de mesleğimi ikinci plana atmıs oluyorum." (K19)

Kadın turist rehberleri çocuklara bağlı olarak iş-aile çatışması alt temasından zaman temelli çatışmayı daha çok yaşamaktadırlar. İşlerini tercih ettikleri dönemlerde, günübirlik ve Anadolu turlarına çıktıkları zaman dilimde anne ve eş olmanın sorumluluklarını yerine getirememekten rahatsızlık duymaktadırlar. Aynı zamanda geniş aile ve akrabaları ile yaşadıkları ilişkilerde de aksaklıklar olmaktadır. Bunu da şu şekilde dile getirmektedirler;

“...Aksakliklar çok fazla yaşıyorum. Ya iyi turlardan vazgeçiyorum. Ya da ailemle yaptı̆̆ım planlardan. Bu sadece eşimle ve çocuğumla değil de kendi ailemle annemle babamla kız kardeşlerimle. Bir plan yapıyoruz benim son anda iptal etme durumum çok oluyor. Genel olarak planlarımızı tam anlamıyla gerçekleştiremiyoruz. Özellikle tatil konularında bir türlü denk gelemiyor. Yaz aylarında genellikle mesleğimi seçiyorum ama klşın aileyi seçiyorum.” (K7)

“...Mesela eşim veya oğlum evde hasta yatarken rahat bir şekilde tura devam edemiyorum, doğal olarak aklım onlarda kalıyor. ”(K11)

Zaman temelli çatışmaya bağlı olarak gerilim temelli çatışmanın ortaya çıktığı söylenebilir. $\mathrm{Ev}$ ve iş arasında kalan kadın turist rehberleri stresli ruh hallerini tartışma ve gerginlik olarak aileye veya tura yansitabilmektedirler. Bunu şu şekilde ifade etmektedirler;

“...Çocuksuz evliyken daha farklı bir ruh hali oluyordu çocukluyken daha farkl oluyor. Çocuk hastaysa mesela veya kreş döneminde çok zorluk çektik her sabah ağllyordu. Illk başta ilk yarım saat tura konsantre olamıyordum mesela. Kreşle konuşuyorum yazışlyorum ister istemez tura moralim bozuk gidiyorum. Turlara yansitiyorum maalesef." (K7)

“...Anadolu turlarına çıktığımda bazı gerginlikler oluyor. Çocuklar özlüyor. Anne neden gelmedin gibi söylemleri olabiliyor." (K18)

“...̈̈zellikle uzun süren doğu ya da batı turlarına çıkmak zorunda kaldiğımda ailede gerginlik yaratabiliyor. Bir anne ve eşin 3 gün ve ya 1 hafta evde olmamast psikolojik anlamda aile üyelerini geriyor. Ben de geriliyorum maalesef, hem yorucu tur programindan hem de ailemin gerginliğinden dolayl." (K11)

Kadınların erkeklere göre daha duygusal olmaları iş hayatlarında zaman zaman kendilerini kötü ve gergin hissetmelerine neden olabilmektedir. Kadın turist rehberleri de işleri nedeniyle özellikle çocukları ile ilgili bazı duygusal durumlarla karşı karşıya kalabilmektedirler.

“...Gün içerisinde işime kendimi verebiliyorum. Fakat akşam otele gidince bir ağlama geliyor. Kızımı özlüyorum. Evimi değil eşimi değil kızımı özlüyorum.” (K13)

“...Son anda hadi ben turu iptal edeyim çocuğum ağllyor diyemiyorum. Aklınız hep orda kalyyor çocuğum ă̆llyor mu diye.” (K21)

Söylemlere göre; kadın turist rehberlerinin mesleklerini yapmaktan keyif aldıklarını fakat aile söz konusu olduğunda işlerinin ikinci plana kaldığını söylemek mümkündür. Bununla birlikte

Demirel, N., Yumuk, Y. ve Hacıoğlu, N. (2021). İş-aile rol çatışması ve kariyer devamlılığı ilişkisi: kadın turist rehberleri üzerine bir değerlendirme / The relation between work- family conflict and career continuity: an evaluation on female tour guides 
maddi kazanç ve rehber olmak için harcanan emek düşünüldüğünde; tura çıkmak onların mesleklerini devam ettirme niyetlerinin önemli bir göstergesidir. Zaman temelli, gerilim temelli ve duygusal açıdan çatışma yaşansa da bunlar minimum düzeydedir. Yaşanan bu çatışmalar ise ailenin ikinci planda kalması durumunda ortaya çıkmaktadır. Mesleği icra ederken birçok sorunla karşılaşan kadın turist rehberi profesyonelleştikçe iş ve aile arasındaki dengeyi kurabilmektedir. Bu dengeyi kurmada en önemli faktör eş desteğidir.

\section{Sonuç ve Öneriler}

Endüstrileşmeyle birlikte iş hayatına katılan kadınların eşlik ve annelik rolleri ve söz konusu rollerin toplum tarafından kadınların öncelikleri olarak atfedilmesi işle çatışma yaşanmasına neden olmakta ve hatta kariyere devam edememe durumu ile sonuçlanabilmektedir. Turizm sektörünün yapısal özellikleri ve çalışma koşulları, aile ve özel hayatından erkeklere kıyasla daha çok fedakârlık etmek durumunda kalan kadınların kariyer hayatlarını daha da zorlaştırmaktadır. Turizm sektöründe kültür elçiliği görevini üstlenen turist rehberleri; mesleklerinin fiziksel güç gerektirmesi, iş güvencelerinin olmaması, sürekli kendilerini yenileme zorunluluklarının bulunması ve çalışma saatlerinin düzensiz olması gibi nedenlerle mesleklerini icra ederken güçlük yaşamaktadırlar (Ahipaşaoğlu, 2006; Eser, 2018). Aile hayatını koruma, ev düzenini sağlama ve çocuk bakma gibi öncelikleri bulunan kadın turist rehberlerinin ise mesleklerini icra etme ve devam ettirme konusunda zorlandıkları daha belirgin olarak fark edilmektedir. Bir turist rehberinin mesleğini sevmesi, kişilik özelliklerinin mesleğiyle uyumlu olması ve sürekli kendini yenilemesi mesleğini devam ettirmesi bakımından gereklidir. Ancak, toplumun bu mesleği yalnızca erkeklerin yapabileceği bir meslek olarak görmeleri ve her defasında kadının aile hayatındaki önceliklerini hatırlatmaları kadınların mesleki kariyerlerini devam ettirmelerine engel oluşturabilmektedir.

21 eylemli kadın ve evli turist rehberiyle gerçekleştirilen bu araştırmada da kadın turist rehberlerinin mesleklerini devam ettirmeleri önündeki en büyük engelin eşleri ve özellikle çocukları olduğu sonucuna varılmıştır. Özellikle daha fazla maddi kazanç sağlamak amacıyla Anadolu turlarına çıan kadın turist rehberleri ailelerinden uzun süre uzak kalmaları nedeniyle işlerini icra ederken yeterince motive olamadıklarını belirtmekte; aile hayatlarından kaynaklı olarak ișleriyle en fazla zaman temelli, davranışsal ve gerilim temelli çatışma yaşadıklarını ortaya koymaktadırlar. Söz konusu araştırma sonuçlarının literatürde yer alan bazı araştırmalarla (Demirbulat, 2014; Köroğlu, Şahin \& Tetik, 2007) uyumlu olduğu görülmektedir. Araştırmada aynı zamanda eş desteğinin mesleği devam ettirmede önemli bir rol oynadığı belirtilmektedir. Eşi turizm sektöründe çalışan ya da turist rehberi olan kadın turist rehberleri mesleklerini icra etmek ve devam ettirmek konusunda çok fazla sorunla karşı karşıya kalmadıklarını ifade etmektedirler. Bu nedenle, her ne kadar kadın ve evli turist rehberlerinin mesleği icra etmeleri ve sürdürebilmeleri zor gibi görünse de, eş desteğini alarak aile ve iş dengesinin sağlanması mesleği sürdürebilme önündeki engellerin ortadan kaldırılmasına destek oluşturmaktadır. Bu noktada günübirlik turlar özellikle çocuk sahibi olan kadın turist rehberleri için bir alternatif teşkil etmektedir.

Kadın turist rehberlerinin özel ve aile hayatları göz önünde bulundurulduğunda; seyahat acentelerine daha çok sayıda acenteye bağlı turist rehberleri çalıştırmaları konusunda öneride bulunulabilir. Ayrıca, kadın turist rehberlerinin dönüşümlü olarak turlara çıkmaları ve böylece ailelerine daha fazla zaman ayırabilmeleri sağlanabilir.

Araştırmaya yalnızca Türkiye'deki eylemli kadın ve evli turist rehberlerinin dâhil edilmiş olması araştırmanın en önemli kısıtını oluşturmaktadır. Sosyal bilimlerde gerçekleştirilen araştırmalarda "kültür" olgusunun araştırma sonucunu etkileyen son derece önemli bir faktör olduğu kabul edilmektedir. Bu nedenle, araştırmanın kadına farklı anlamlar yüklendiği Batı kültürlerinde tekrar edilmesinin araştırma sonucunu değiştirebileceği düşünülmektedir. Farklı ülkelerde aynı anda nitel ve nicel araştırma yöntemleri kullanılarak büyük örneklem üzerinde gerçekleştirilecek

Demirel, N., Yumuk, Y. ve Hacıoğlu, N. (2021). İş-aile rol çatışması ve kariyer devamlılığı ilişkisi: kadın turist rehberleri üzerine bir değerlendirme / The relation between work-family conflict and career continuity: an evaluation on female tour guides 
Turist Rehberliği Dergisi (TURED) \& Yıl. 2021, Cilt. 4, Sayı. 1

Journal of Tour Guiding (JOTOG) \& Year. 2021, Volume. 4, Issue. 1

araştırmalar söz konusu kavramlar arasındaki ilişkiyi daha kapsamlı ortaya koyması bakımından önemlidir.

\section{Kaynakça}

Acun, A. (2016). İş aile çatışmast ve turist rehberlerinin işten ayrllma niyetlerine etkisi. (Tez No. 442865) [Yüksek lisans tezi, Balıkesir Üniversitesi]. YÖK Tez Merkezi. https://tez.yok.gov.tr/UlusalTezMerkezi/giris.jsp.

Acuner, Ş. A. (2019). Kadın çalışanların kariyer geliştirme sürecinde karşılaştıkları sorunlar. Uluslararasi Íktisadi ve İdari Incelemeler Dergisi, 23, 35-52.

Adak, N. (2007). Kadınların ikilemi: İş ve aile yaşamı. Sosyoloji Dergisi, 17.

Ahipaşaoğlu, S. (2006). Turizmde rehberlik. (2. Baskı). Gazi Kitabevi.

Altıok Gürel, P. (2018). İş-yaşam dengesini sağlayan faktörlerin kadın akademisyenler için belirlenmesi: Lojistik regresyon analizi. Kadın Araştırmaları Dergisi, 16, 31-44.

Arslan, A., \& Şimşek, G. (2018). Kadın turist rehberlerinin yaşadıkları mesleki sorunlar: Aydın turist rehberleri örneği. Journal of Travel \& Tourism Research, 13, 23-49.

Arthur, M. B., Arthur, M. B., Hall, D. T., \& Lawrence, B. S. (Eds.). (1989). Handbook of career theory. Cambridge University Press.

Aycan, Z. \& Eskin, M. (2005). Relative contributions of childcare, spousal support, and organizational support in reducing work-family conflict for men and women: The case of Turkey. Sex Roles, 53, 7/8, 453-471.

Ayoğul, H, (2017). Kadın çalışanların kariyer engelleri: Eskişehir'de bir araştırma (Tez No. 463479) [Yüksek lisans tezi, Eskişehir Anadolu Üniversitesi] YÖK Tez Merkezi. https://tez.yok.gov.tr/UlusalTezMerkezi/giris.jsp

Berg, B. L., \& Lune, H. (2015). Sosyal bilimlerde nitel araştırma yöntemleri. (H. Aydın, Çev.) Eğitim Yayınevi.

Chen, H. , Ayoun, B. \& Eyoun, K. (2018). Work-family conflict and turnover intentions: A study comparing China and U.S. hotel employees. Journal of Human Resources in Hospitality \& Tourism, 17(2), 247-269.

Creswell, J. W. (2018). Nitel Araştırma Yöntemleri. (Çev.: Mesut Bütün, Selçuk Beşir Demir). Siyasal Kitabevi.

Demirbulat, Ö. G. (2014). Profesyonel turist rehberliği mesleğinin aile yaşantısı üzerindeki etkisini belirlemeye yönelik bir inceleme. Turizm ve Araştırma Dergisi, 3(2), 21-41.

Doğan, H., Üngüren, E., \& Kesgin, D. D. (2010). Meslek ve aile yaşamı ilişkisi: Profesyonel turist rehberlerine yönelik bir araştırma. Journal of Yasar University, 5(20).

Eser, S. (2018). Meslek olarak turist rehberliği. Turist rehberliği içinde (Ed: S. Eser, S. Şahin ve A.C. Çakıc1) s. 25-46. Detay Yayıncılık.

Eşitti, B. (2018). Konaklama işletmelerinde iş değerlerinin işten ayrılma niyetine etkileri: iş-aile-iş çatışmasının aracı rolü. Verimlilik Dergisi, 3, 235-257.

Ezzedeen, S. R., \& Ritchey, K. G. (2009). Career advancement and family balance strategies of executive women. Gender in management: An International Journal, 24(6), 388-411.

Frone, M. R. \& Rice, R. W. (1987). Work-Family Conflict: The Effect of Job and Family Involvement. Journal of Occupational Behaviour, 8(1), 45-53.

Gamor, E., Amissah, E. F., Amissah, A. \& Nartey, E. (2018). Factors of work-family conflict in the hospitality industry in Ghana. Journal of Human Resources in Hospitality \& Tourism, 17(4), 482501.

Greenhaus, J. H. \& Beutell, N. J. (1985). Sources of conflict between work and family roles. The Academy of Management Review, 10(1), 76-88.

Gürbüz, S., \& Şahin, F. (2014). Sosyal bilimlerde araştırma yöntemleri. Seçkin Yayıncılık.

Demirel, N., Yumuk, Y. ve Hacıoğlu, N. (2021). İş-aile rol çatışması ve kariyer devamlılığı ilişkisi: kadın turist rehberleri üzerine bir değerlendirme / The relation between work- family conflict and career continuity: an evaluation on female tour guides 
Turist Rehberliği Dergisi (TURED) \& Yıl. 2021, Cilt. 4, Sayı. 1

Journal of Tour Guiding (JOTOG) \& Year. 2021, Volume. 4, Issue. 1

Güzel, B. ve Özgül, E. (2014). Turizm işletmelerinde iş-aile yaşamı çatışması, Editör (Ş. A. Tükeltürk, N. Ş. Perçin ve B. Güzel), Turizm işletmelerinde çalışan ilişkileri yönetimi (405-422), Detay Yayıncilik.

Helmy, O. S. (2018). Work-Family conflict and family-work conflict on employees turnover intentions in the tourism industry. International Journal of Heritage, Tourism and Hospitality, $12(2 / 2), 400-410$.

http://tureb.org.tr/tr/RehberIstatistik/ (Erişim Tarihi: 05.03.2020).

https://sozluk.gov.tr/?kelime=an (Erişim Tarihi: 05.03.2020).

https://www.etymonline.com/word/career (Erişim Tarihi: 05.03.2020).

Kara, E. (2018). İş-aile çatışmasının işten ayrılma niyeti üzerine etkisini belirlemeye yönelik turizm sektöründe bir araştırma: Edremit Körfezi örneği. İdealkent - Kent Araştırmaları Dergisi, 24, 733-750.

Kargiglioğlu, Ş. \& Özer, E. Z. (2018). Toplumsal roller ve kadın. Turizm ve kadın içinde; Editörler Gül Erkol Bayram, Ali Turan Bayram ve Özlem Altunöz Sürücü. Ankara: Detay Yayıncılık.

Kozak, M. (2014). Bilimsel araștırma: tasarım, yazım ve yayım teknikleri, Detay Yayıncılık.

Köroğlu, Ö. , Şahin, S. \& Tetik, N. (2007). Turizm sektöründe bayan çalışanların sorunları: Bayan profesyonel turist rehberlerinin karşılaştıkları sorunları belirlemeye yönelik sinırlı bir örneklem üzerinde araştırma. 1. Ulusal Turizm Kongresi, Sakarya. Detay Yayıncılık.

Kulualp, H. G. \& Savaşkan, Y. (2019). İş-aile çatışmasının kadın çalışanların demografik özellikleri açısından değerlendirilmesi (ss. 198-218). Econder I. Uluslararası İktisat, İşletme ve Sosyal Bilimler Kongresi Bildiri E-Kitabı. 18 - 20 Ekim 2019, Karabük.

Masadeh, M., Al-Ababneh, M., Al-Sabi, S., \& Allah, M. H. (2018). Female tourist guides in Jordan: Why so few?. European Journal of Social Sciences, 56(2), 89-102.

Netemeyer, G. Richard., Boles, S. James. \& McMurrian, R. (1996). Development and validation of work family conflict and family work conflict scales. Journal of Applied Psychology, 81(4), 400410.

Parasuraman, S. \& Greenhaus, J. H. (2002). Toward reducing some critical gaps in work-family research. Human Resource Management Review 12, 299-312.

Patton, W. (2013). Conceptualising women's working lives: Moving the boundaries of discourse (Vol. 5). Springer Science \& Business Media.

Savaşkan, Y., \& Kulualp, G. H. (2019). Kadın çalışanlarda iş-aile çatışması, duygusal emek ve işten ayrılma niyeti arasındaki ilişki. International Journal of Economic \& Administrative Studies, 25, 215-234.

Seçilmiş, C., \& K1lıç, İ. (2017). Örgütsel güven, iş-aile çatışması ve işten ayrılma niyeti ilişkisinin belirlenmesi: Seyahat acentelerinde bir uygulama. Turizm Akademik Dergisi, 4(1), 65-79.

Tükeltürk, Ş. A., \& Perçin, N. Ş. (2008). Turizm sektöründe kadın çalışanların karşılaştıkları kariyer engelleri ve cam tavan sendromu: Cam tavanı kırmaya yönelik stratejiler. Yönetim Bilimleri Dergisi, 6(2), 113-128.

Vong, L.T. \& Tang, W.S. (2017). The mediating effect of work-family conflict in the relationship between job stress and intent to stay: The case of tourism and hospitality workers in Macau. Journal of Human Resources In Hospitality \& Tourism,16(1), 39-55.

White, B. (1995). The career development of successful women. Women in Management Review.

Yang, Y \& Peng, M. M. (2018). Impacts of work-family conflict on female hospitality employees' job outcomes. Journal of China Tourism Research,14(4), 428-444.

Zengin, B., Erkol, G. \& Eker, N. (2014). Rehberlik mesleğinde bir engel olarak cinsiyet ayrımcılı̆̆ı: Bayan turist rehberleri üzerine bir araştırma, 15. Ulusal Turizm Kongresi, 1144-1159.

Demirel, N., Yumuk, Y. ve Hacıoğlu, N. (2021). İş-aile rol çatışması ve kariyer devamlılığı ilişkisi: kadın turist rehberleri üzerine bir değerlendirme / The relation between work- family conflict and career continuity: an evaluation on female tour guides 
Turist Rehberliği Dergisi (TURED) \& Yıl. 2021, Cilt. 4, Sayı. 1

Journal of Tour Guiding (JOTOG) \& Year. 2021, Volume. 4, Issue. 1

\section{ETİK ve BİLIMSEL ILKELER SORUMLULUK BEYANI}

Bu çalışmanın tüm hazırlanma süreçlerinde (veri toplama, yazım vb.), tüm etik kurallara ve bilimsel atıf gösterme ilkelerine riayet edildiğini, herhangi bir hataya mahal vermemek için yayımdan önce makalenin bir intihal programı aracılığıyla da kontrol edildiğini yazarlar beyan eder. Ayrıca yazarlar aşağıda sıralanan hususları kabul etmiştir:

1. Çalışmada yer alan ve kullanılan tüm kaynaklara, bilimsel araştırma yöntemleri ve etik ilkeler doğrultusunda atıf yapılmıştır.

2. Çalışmada tüm yazarların akademik-bilimsel olarak doğrudan ve ortak katkısı vardır.

3. Bu çalışma, yazarların özgün bir çalıșmasıdır.

4. Bütün yazarlar dergiye gönderilen makaleyi görmüş ve sonuçlarını onaylamıştır.

5. Çalışmada kullanılan denek/deneklere ilişkin herhangi bir etik ihlal yapılmamış, kullanılan tüm veri toplama yöntemlerinde bilimsel etik ilkelere göre hareket edilmiştir

6. Çalışma daha önceden bilimsel bir toplantıda sunulan özet veya bu çalışmanın daha kısa hali ise, makalede bu durum belirtilmiştir.

7. Çalışmada, hiçbir suç unsuru veya kanuna aykırı ifade bulunmamakla birlikte, araştırma yapılırken kanuna aykırı herhangi bir yöntem kullanılmamış olup, çalışma ile ilgili tüm yasal izinler alınmış ve etik kurallara uygun hareket edilmiştir.

Aksi bir durumun tespiti halinde Turist Rehberliği Dergisi’nin hiçbir sorumluluğu olmayıp, tüm sorumluluk makale yazarlarına aittir.

Tarih $\quad: 27 / 05 / 2021$

Sorumlu Yazar : : Nilgün DEMIREL

Demirel, N., Yumuk, Y. ve Hacıoğlu, N. (2021). İş-aile rol çatışması ve kariyer devamlılığı ilişkisi: kadın turist rehberleri üzerine bir değerlendirme / The relation between work-family conflict and career continuity: an evaluation on female 